\title{
Kemampuan Koneksi Matematis Siswa SMP dalam Menyelesaikan Soal Cerita: Studi Kasus di SMP Negeri 3 Cibadak
}

\author{
Aspuri $^{1 *}$, Heni Pujiastuti ${ }^{2}$ \\ ${ }^{1}$ SMP Negeri 3 Cibadak, Jalan Arif Rahman Hakim KM.07 Lebak Banten, Indonesia. \\ ${ }^{2}$ Universitas Sultan Ageng Tirtayasa, Jl. Raya Jakarta KM 4 Pakupatan Serang, Banten, Indonesia. \\ * Korespondensi Penulis. E-mail:yusufaspuri@gmail.com, Telp: +6281295722511
}

Article received: 03-01-19, article revised: 12-02-2019, article published: 31-03-2019

DOI : 10.25273/jipm.v7i2.3651

\begin{abstract}
Abstrak
Penelitian ini bertujuan untuk mengetahui kemampuan koneksi matematis siswa dalam menyelesaikan soal cerita, khususnya pada materi Kesebangunan. Penelitian ini merupakan jenis penelitian deskriptif dengan pendekatan kualitatif. Subjek penelitiannya yaitu siswa kelas IX SMP Negeri 3 Cibadak yang terdiri atas 25 siswa. Instrumen yang digunakan diantaranya yaitu tes kemampuan koneksi matematis, wawancara dan dokumentasi. Berdasarkan hasil penelitian diperoleh bahwa kemampuan koneksi matematis siswa dalam menyelesaikan soal cerita masih rendah. Hal ini terbukti dari Persentase kemampuan koneksi matematis tiap indikator koneksi kemampuan siswa dalam menuliskan model matematis hanya 48\%, kemampuan menghubungkan konsep $60 \%$ dan melakukan koneksi prosedur 40\%. Dari hasil tes terlihat bahwa kesulitan koneksi matematis siswa belum mampu menggunakan semua informasi dari masalah yang ada dalam soal cerita, belum mampu membuat model matematis dari permasalahan yang dimunculkan dalam soal, sehingga terjadi kesalahan dalam menghubungkan dengan koneksi konsep dan prosedur. Akibatnya, diperoleh jawaban yang tidak relevan. Hendaknya guru dalam proses pembelajaran memfasilitasi siswa untuk mengembangkan kemampuan koneksi matematis siswa dalam menyelesaikan masalah soal cerita.
\end{abstract}

Kata Kunci: Koneksi Matematis, Soal Cerita, Koneksi Pemodelan, Koneksi Konsep dan Koneksi Prosedur

The Ability of Mathematical Connection Students SMP in Solving About Story

\begin{abstract}
This study aims to determine students' mathematical connection skills in solving story problems, especially in congruence material. This research is a type of descriptive research with a qualitative approach. The research subjects were class IX students of SMP Negeri 3 Cibadak consisting of 25 students. The instruments used include the test of mathematical connection ability, interviews and documentation. Based on the results of the study, it was found that the mathematical connection ability of students in solving story problems was still low. This is evident from the percentage of mathematical connection ability of each connection indicator students' ability to write mathematical models is only $48 \%$, the ability to connect concepts $60 \%$ and connect procedures $40 \%$. From the test results it can be seen that the mathematical connection difficulties students have not been able to use all the information from the problems in the story problem, have not been able to make a mathematical model of the problems raised in the problem, resulting in errors in connecting with connection concepts and procedures. As a result, irrelevant answers are obtained. Teachers should in the learning process facilitate students to develop students' mathematical connection skills in solving problems about stories.
\end{abstract}

Keywords: Mathematical Connections, Story Problems, Connection Modeling, Connections Concepts and Connections Procedures 


\section{JIPM (Jurnal Ilmiah Pendidikan Matematika), 7(2), Maret 2019- 125}

Aspuri, Heni Pujiastuti

\section{PENDAHULUAN}

Proses pembelajaran matematika sedapat mungkin untuk terjadinya sinkronisasi antara konten matematika dengan kehidupan nyata. Hal ini diperlukan untuk untuk mentransfer pengetahuan matematika dan keterampilan yang diperoleh di sekolah-sekolah dengan kehidupan nyata yang memerlukan individu untuk berpikir, menghitung, perkiraan atau menerapkan pengetahuan matematika untuk memecahkan masalah kehidupan nyata dan juga untuk berkomunikasi secara matematis (Baki, 2009).

Kemampuan koneksi matematis menjadi salah satu standar proses dalam pembelajaran matematika. Dalam (NCTM, 2000) disebutkan bahwa terdapat lima kemampuan dasar matematika yang merupakan standar proses pendidikan matematika yaitu "(1) kemampuan pemecahan masalah (problem solving); (2) kemampuan bernalar (reasonning); (3) Kemampuan berkomunikasi (communication); (4) Kemampuan membuat koneksi (connection) dan (5) Kemampuan representasi (representation)". Maka jelas bahwa kemampuan dalam menyelesaikan masalah ini erat kaitannya dengan kemampuan koneksi matematis.

Kemampuan untuk menjelaskan keterkaitan antar konsep merupakan bagian dari kemampuan koneksi matematika. (Kaur \& Lam, 2010) menyebut koneksi matematis sebagai kemampuan melihat dan membuat hubungan antara ide-ide matematis, antara matematika dengan subjek lain, atau antara matematika dengan kehidupan seharihari. Menurut Coxford dalam (Pratiwi Dwi Warih, I Nengah Parta, 2016) mengemukakan bahwa kemampuan koneksi matematis meliputi: (1) mengkoneksikan pengetahuan konseptual dan prosedural, (2) menggunakan matematika pada topik lain (other curriculum areas), (3) menggunakan matematika dalam aktivitas kehidupan, (4) melihat matematika sebagai satu kesatuan yang terintegrasi, (5) menerapkan kemampuan berfikir matematis dan membuat model untuk menyelesaikan masalah dalam pelajaran lain (6) mengetahui koneksi diantara topik-topik dalam matematika, dan (7) mengenal berbagai representasi untuk konsep yang sama. Koneksi Siswa yang dapat membuat koneksi antar konsep matematika akan memiliki pemahaman yang mendalam dan tahan lama (NCTM, 2000).

Kemampuan koneksi matematis harus ditumbuhkan pada diri siswa sebagai kemampuan dalam proses menyelesaikan masalah. Menyelesaiakan masalah salah satunya dalam bentuk soal cerita. Masalah verbal atau soal cerita mencakup tugas-tugas matematika murni yang dikemas pada situasi dunia nyata, yang mengharuskan siswa untuk menanggalkan pengemasan dan menyelesaikannya. Hal ini meng indikasikan bahwa masalah verbal dalam matematika merupakan jenis masalah yang dirancang untuk membantu siswa menerapkan konsepkonsep matematika yang abstrak untuk situasi pada dunia nyata. Soal cerita merupakan masalah matematika yang ditulis dalam bentuk kalimat-kalimat dan siswa diminta menghubungkan antara informasi yang diketahui dan yang tidak diketahui (Sajadi, Amiripour, \& Rostamy-malkhalifeh, 2013).

Ketika siswa mengembangkan pandangan matematika sebagai satu kesatuan yang terhubung dan terintegrasi, mereka akan memiliki lebih sedikit kecenderungan untuk melihat matematika sebagi keterampilan dan konsep secara terpisah. Jika pemahaman konseptual terkait prosedur, siswa tidak akan menganggap matematika sebagai set sewenang-wenang aturan. Integrasi prosedur dan konsep ini harus menjadi pusat di sekolah matematika (NCTM, 2000). Dengan demikian, pemahaman hubungan 
antar konsep matematis menjadi sesuatu yang penting dalam pembelajaran matematika. Hubungan atau keterkaitan antar konsep dapat dimaknai bahwa suatu konsep dapat menjadi prasyarat bagi pemahaman konsep lainnya (Prayitno, 2018)

Dalam (NCTM, 2000) siswa harus dapat menuliskan masalah kehidupan seharihari dalam bentuk model matematika. Pada aspek ini, diharapkan siswa mampu mengkoneksikan antara masalah pada kehidupan sehari-hari dan matematika. Menuliskan konsep matematika yang mendasari jawaban. Praktek pembelajaran di kelas matematika di mana matematika disajikan sebagai keterampilan dan konsep-konsep yang berhubungan erat satu sama lain. Di sini, siswa didorong untuk melihat matematika sekolah sebagai terletak dan terhubung ke konteks yang lebih luas dari pengetahuan matematika (Kaur \& Lam, 2010). Pada aspek ini, diharapkan siswa mampu menuliskan konsep matematika yang mendasari jawaban guna memahami keterkaitan antar konsep matematika yang akan digunakan. Menuliskan hubungan antar obyek dan konsep matematika. Pada aspek ini, diharapkan siswa mampu menuliskan hubungan antar konsep matematika yang digunakan dalam menjawab soal yang diberikan.

Aspek koneksi dalam kegiatan pemecahan masalah matematika menurut Evitts (Businskas, 2008) membagi lima aspek koneksi dalam kegiatan pemecahan masalah matematika. Lima aspek koneksi tersebut, meliputi koneksi pemodelan, koneksi prosedur-konsep, koneksi struktural, koneksi representasi, dan koneksi antar konsep matematika. Proses penyelesaian soal cerita melibatkan pemodelan dan perhitungan matematis, penelitian ini fokus pada tiga aspek koneksi, yaitu koneksi pemodelan, koneksi konsep, dan koneksi prosedur.
Koneksi pemodelan merupakan koneksi yang dilakukan ketika menerjemahkan situasi dan menuliskan ke bentuk matematis. Koneksi konsep yaitu koneksi yang dilakukan ketika menghubungkan konsep-konsep matematika. Koneksi prosedur merupakan koneksi yang dilakukan ketika menggunakan prosedur untuk menyelesaikan soal.

Penelitian ini bertujuan untuk mendeskripsikan kemampuan koneksi matematis siswa SMP Negeri 3 Cibadak dalam menyelesaikan soal cerita materi kesebangunan. Pemilihan materi kesebangunan dikarenakan materi tersebut banyak koneksi matematis di dalamnya.

\section{METODE}

Penelitian ini merupakan jenis penelitian kualitatif deskriptif. Penelitian ini dilaksanakan untuk menganalisis dan mendeskripsikan kemampuan koneksi matematis siswa kelas IX A dalam materi kesebangunan yang berpedoman pada terpenuhi atau tidaknya indikator-indikator koneksi matematis. Penelitian ini dilaksanakan di SMP Negeri 3 Cibadak. Subjek dari penelitian ini yaitu siswa kelas IX A yang berjumlah 25 siswa dengan kemampuan heterogen.

Teknik pengumpulan data yang digunakan dalam penelitian ini yaitu melakukan kegiatan pendahuluan, menyusun tes kemampuan koneksi matematis, mengkumpulkan data, menganalisis data, dan menarik kesimpulan. Data yang dikumpulkan berupa hasil tes kemampuan koneksi matematis 25 siswa yang sudah ditentukan sebelumnya. Instrumen utama adalah peneliti. Instrumen pendukung pada penelitian ini berupa tes. Tes yang digunakan pada penelitian ini adalah tes kemampuan koneksi matematis yang terdiri dari 2 soal berupa 
soal-soal dengan mengaitkan materi kesebangunan dengan masalah kehidupan seharihari dalam bentuk soal cerita.

Soal tes koneksi tes yang digunakan diambil daru buku siswa kemendikbud. Selain itu, rubrik penilaian tes disusun berdasarkan indikator koneksi matematis yang telah ditentukan. Pada setiap indikator dijabarkan kemungkinan proses yang dituliskan siswa. Selanjutnya, kemampuan koneksi matematis siswa dianalisis menurut tiga aspek koneksi. Indikator dari masingmasing aspek koneksi ditunjukkan pada Tabel 1.

Tabel 1.

Indikator Koneksi Matematis Siswa dalam Menyelesaikan Soal Cerita

\begin{tabular}{|c|c|c|}
\hline No & $\begin{array}{c}\text { Aspek } \\
\text { Koneksi }\end{array}$ & Indikator \\
\hline 1 & $\begin{array}{l}\text { Koneksi } \\
\text { pemodelan }\end{array}$ & 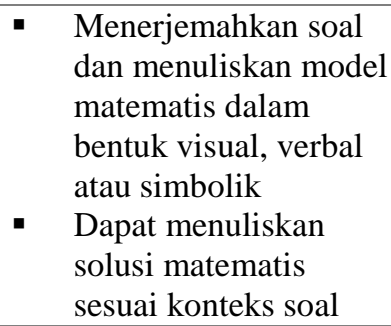 \\
\hline 2 & $\begin{array}{l}\text { Koneksi } \\
\text { konsep }\end{array}$ & $\begin{array}{l}\text { Menghubungkan } \\
\text { konsep-konsep } \\
\text { matematika, }\end{array}$ \\
\hline 3 & $\begin{array}{l}\text { Koneksi } \\
\text { prosedur }\end{array}$ & $\begin{array}{l}\text { Melakukan prosedur } \\
\text { operasi perhitungan } \\
\text { perbandingan }\end{array}$ \\
\hline
\end{tabular}

Berdasarkan indikator tersebut peneliti dapat menentukan apakah siswa memenuhi masing-masing indikator koneksi atau tidak. Data yang diperoleh kemudian disesuaikan dengan hasil penilaian tes.

\section{HASIL DAN PEMBAHASAN}

Kegiatan awal penelitian yang dilakukan adalah menentukan materi yang akan dijadikan instrumen kemampuan koneksi matematis melalui sebuah tes berbentuk uraian. Kemudian dilakukan tes kepada 25 siswa yang sudah ditentukan. Tes dilakukan selama 40 menit. Selanjutnya data diolah dan dianalsis berdasarkan rubrik penilaian.
Bentuk soal cerita koneksi matematis yang diberikan adalah sebagai berikut.

1. Sebuah gedung mempunyai panjang bayangan $56 \mathrm{~m}$ di atas tanah mendatar. Pada saat yang sama seorang siswa dengan tinggi 1,5 m mempunyai bayangan $3,5 \mathrm{~m}$. Tinggi gedung sebenarnya adalah....

2. Sebuah foto berukuran tinggi $30 \mathrm{~cm}$ dan lebar $20 \mathrm{~cm}$ ditempel pada sebuah karton. Sisa karton di sebelah kiri, kanan, atas foto $2 \mathrm{~cm}$. Jika foto dan karton sebangun, sisa karton di bawah foto adalah..

Berdasarkan hasil analisis mengenai jawaban tes dalam menyelesaikan soal cerita materi kesebangunan dengan aspek koneksi pemodelan, koneksi konsep dan koneksi prosedur. Adapun skor hasil tes dari 25 siswa pada setiap soalnya disajikan dalam tabel 2 berikut.

Tabel 2. Klasifikasi skor hasil tes siswa

\begin{tabular}{cccc}
\hline $\begin{array}{c}\text { No } \\
\text { Soal }\end{array}$ & skor & $\begin{array}{c}\text { Banyak } \\
\text { siswa }\end{array}$ & $\begin{array}{c}\text { Persentase } \\
\text { siswa }\end{array}$ \\
\hline 1 & 8 & 12 & $48 \%$ \\
& 6 & 10 & $40 \%$ \\
& 2 & 3 & $12 \%$ \\
\hline 2 & 8 & 8 & $32 \%$ \\
& 4 & 12 & $48 \%$ \\
& 2 & 5 & $20 \%$ \\
\hline
\end{tabular}

Pada soal no 1, siswa diminta menentukan ukuran sisi antara ukuran gambar dan sebenarnya yang bersesuaian dalam konteks kesebagunan yang berkaitan dengan masalah kehidupan sehari-hari. Berdasarkan hasil analisis, diketahui ada 12 siswa atau $48 \%$ yang mendapat skor 8 menjawab dengan indikator koneksi yang lengkap dalam arti siswa sudah mampu membuat koneksi pemodelan, mampu menghubungkan dengan koneksi konsep kesebangunan dan koneksi prosedur perhitungan perbandingan dengan benar. Sedangkan pada soal no 2 sebagian besar siswa kelas IXA belum mampu menyelesaikan soal sesuai dengan indikator koneksi sebanyak $20 \%$ atau ada 5 siswa meraih skor 2 , ada $48 \%$ siswa atau 
12 siswa memperoleh skor 4 dan yang mampu menyelesaikan dengan koneksi lengkap sesuai aspek indikator dengan skor
8 sebanyak $32 \%$ hanya 8 siswa. Contoh hasil jawaban no 1 siswa yang mendapat skor sempurna sebagai berikut.

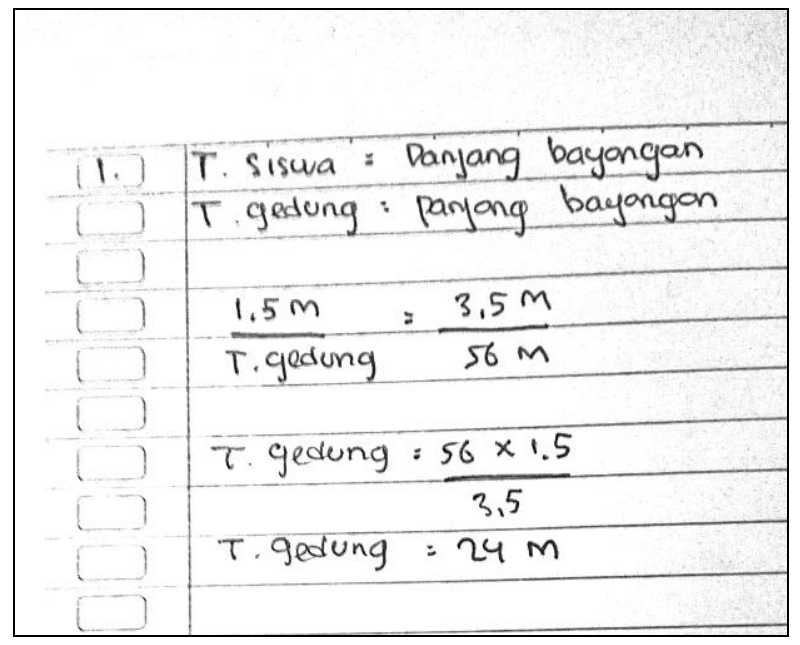

Gambar 1. Jawaban siswa dengan koneksi lengkap

Pada soal no 1 siswa yang mendapat skor sempurna, sudah mampu membuat pemodelan, mampu menghubungkan dengan konsep kesebangunan dan prosedur perhitungan perbandingan dengan benar. Sedangkan pada soal no 2 sebagain besar siswa belum mampu menyelesaikan soal sebanyak $68 \%$ hanya meraih skor 4 dan skor
2 dan yang mampu menyelesaikan dengan lengkap hanya 8 siswa. Dari beberapa siswa mengatakan bahwa mereka tidak paham maksud soal yang diberikan dan tidak terbayang apa yang harus mereka lakukan pertama kali dalam menyelsaikan soal tersebut. Berikut contoh hasil jawaban siswa yang meraih skor 2 .

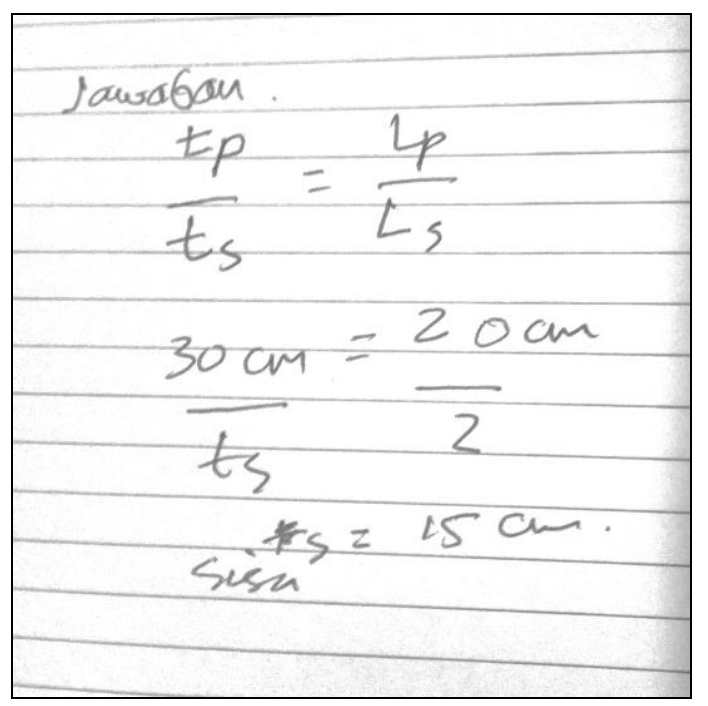

Gambar 2. Jawaban siswa no 2 dengan koneksi tidak lengkap

Dari jawaban siswa tersebut maka siswa jelas tidak memiliki gambaran bagaimana harus menyelesaikan soal cerita tersebut. langkah siswa tersebut dapat dideskripsikan pada tabel 3 sebagai berikut. 
Tabel 3. Deskripsi langkah kemampuan koneksi dalam penyelesaian soal

\begin{tabular}{ll}
\hline No & \multicolumn{1}{c}{ Deskripsi penyelesaian } \\
\hline 1 & $\begin{array}{l}\text { Belum dapat menerjemahkan cerita ke } \\
\text { dalam bentuk gambar } \\
\text { Tidak dapat menghubungkan konsep } \\
\text { ukuran panjang dengan menentukan } \\
\text { sisa panjang foto dan karton } \\
\text { memodelkannya dengan } x\end{array}$ \\
& $\begin{array}{l}\text { Dapat menentukan solusi penyelesaian } \\
\text { dengan menggunakan konsep } \\
\text { perbandingan kesebangunan }\end{array}$ \\
& $\begin{array}{l}\text { Tidak dapat melakukan prosedur } \\
\text { perhitungan perbandingan }\end{array}$ \\
Tidak dapat menentukan hasil akhir \\
yang relevan
\end{tabular}

Siswa belum mampu mempu menterjemahkan soal cerita ke dalam representasi gambar sehingga tidak terhubung koneksi konsep yang dimaksud. Sementara siswa sudah mampu memodelkan cerita menjadi notasi simbol tetapi tidak sesuai konteks cerita yang diberikan, sudah mampu membuat koneksi konsep dengan menuliskan konsep perbandingan sisi-sisi yang bersesuaian tetapi siswa melakukan prosedur perhitungan yang tidak sesuai prosedur perhitungan. Dari beberapa yang mendapat skor rendah pada soal no 2 mengatakan bahwa mereka tidak mampu membuat gambar dari soal cerita sehingga mereka merasa bingung menentukan sisi-sisi mana yang memiliki perbandingan yang sama itu. Sedangkan jawaban no 2 siswa yang mendapat skor sempurna berikut jawabannya.

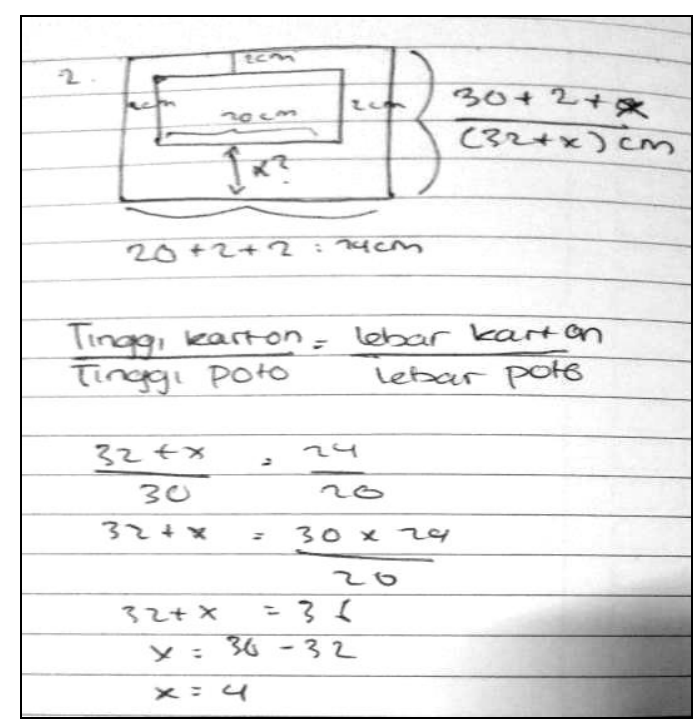

Gb 3. Jawaban siswa no 2 dengan skor 8

Berdasarkan jawaban siswa no 2 tersebut maka diperoleh bahwa siswa sudah mampu memodelkan cerita, mampu menghubungkan konsep kesebangunan dengan konsep bangun datar dan konsep ukuran panjang, mampu melakukan operasi perhitungan perbandingan. Deskripsi langkah kemampuan koneksi matematis siswa tersebut dalam menyelesaikan soal tersebut dapat dilihat pada tabel 4 berikut. 
Tabel 4. Deskripsi langkah kemampuan koneksi dalam penyelesaian soal

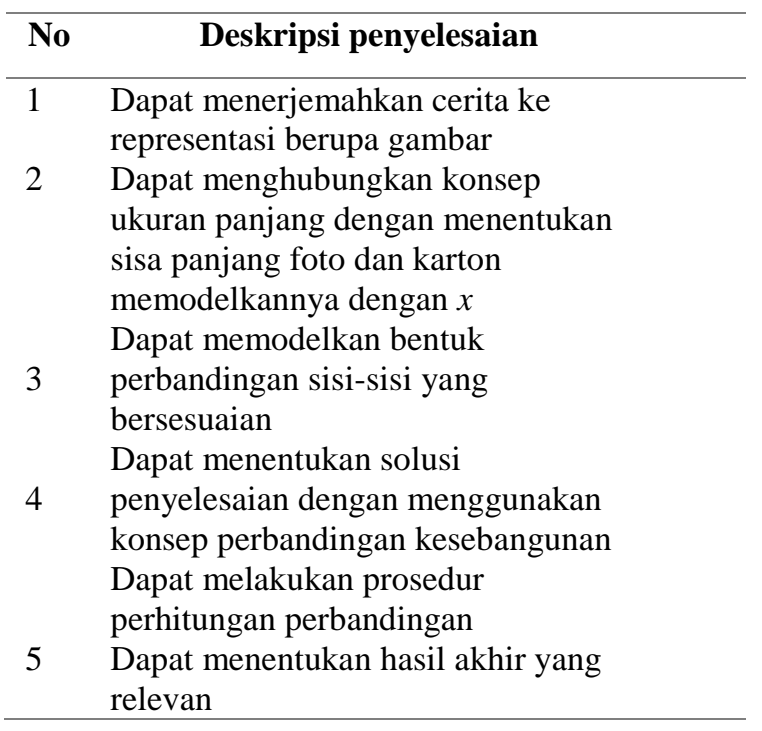

Dari tabel persentase kemampuan koneksi matematis tiap indikator di bawah ini, diketahui bahwa siswa sebagian besar belum mampu atau masih rendah kemampuan menerjemahkan soal cerita dalam menuliskan model matematis, menuliskan solusi matematis sesuai konteks, menghubungkan konsep-konsep matematika dan melakukan operasi prosedur perhitungan. Hal ini sesuai dengan pendapat Montague dalam (Sajadi et al, 2013) bahwa Proses menyelesaikan soal cerita membutuhkan kemampuan siswa dalam menerjemahkan soal kedalam bentuk matematika, menemukan konsep dan prosedur matematika sehingga mampu menemukan solusinya.

Tabel 5. kemampuan koneksi matematis siswa

\begin{tabular}{llc}
\hline \multicolumn{1}{c}{$\begin{array}{c}\text { Aspek } \\
\text { Koneksi }\end{array}$} & \multicolumn{1}{c}{ Indikator } & $\begin{array}{c}\text { Persentase } \\
\text { siswa }\end{array}$ \\
\hline $\begin{array}{l}\text { Koneksi } \\
\text { pemodelan }\end{array}$ & $\begin{array}{l}\text { Siswa mampu } \\
\text { menuliskan model } \\
\text { matematis }\end{array}$ & $48.00 \%$ \\
& $\begin{array}{l}\text { Dapat menuliskan } \\
\text { solusi matematis } \\
\text { sesuai konteks soal }\end{array}$ & $54.00 \%$ \\
\hline $\begin{array}{l}\text { Koneksi } \\
\text { konsep }\end{array}$ & $\begin{array}{l}\text { Menghubungkan } \\
\text { konsep-konsep } \\
\text { matematika }\end{array}$ & $60.00 \%$ \\
\hline $\begin{array}{l}\text { Koneksi } \\
\text { prosedur }\end{array}$ & $\begin{array}{l}\text { Melakukan operasi } \\
\text { perhitungan } \\
\text { perbandingan }\end{array}$ & $40.00 \%$ \\
\hline
\end{tabular}

Berdasarkan data persentase kemampuan koneksi matematis siswa tiap indikator, tidak ada indikator koneksi yang terpenuhi sesuai dengan batas memenuhi minimal $65 \%$. Hasil kemampuan siswa dalam menuliskan model matematis hanya $48 \%$, kemampuan menghubungkan konsep $60 \%$ dan melakukan koneksi prosedur $40 \%$. Soal cerita masih menjadi kesulitan bagi siswa dalam penyelesaian masalah. Hal ini sependapat dengan penelitian (Sajadi et al., 2013) bahwa Soal cerita menimbulkan kesulitan bagi banyak siswa karena proses penyelesaiannya yang kompleks.

Sedangkan persentase skor yang diperoleh siswa secara keseluruhan hanya mencapai 50,5 \% yang artinya masih jauh dari harapan ketercapain dari kemampuan koneksi matematis $65 \%$.

Hasil penelitian di atas hampir sama dengan penelitian yang dilakukan penelitian lain dalam hal kemampuan siswa dalam menyelesaikan soal berbentuk cerita yang menunjukkan bahwa koneksi matematika siswa dalam menyelesaikan soal cerita materi himpunan masih rendah (Lestari, 2017). Peran guru sangat penting dalam membangun kemampuan koneksi matematis siswa. Berdasarkan hasil temuan di lapangan ternyata indikator mencari hubungan berbagai representasi konsep dan prosedur masih merupakan indikator yang memperoleh tingkat capaian terendah. Oleh karena itu perlu adanya suatu usaha latihan terencana dengan pemberdayaan potensi diri siswa agar dapat memunculkan ide atau mengemukakan pendapatnya sendiri (Muhammad \& Fauzi, 2011).

\section{SIMPULAN}

Berdasarkan hasil analisis dan pembahasan, maka dapat disimpulkan kemampuan koneksi matematis siswa dalam me- 


\section{JIPM (Jurnal Ilmiah Pendidikan Matematika), 7(2), Maret 2019- 131 \\ Aspuri, Heni Pujiastuti}

nyelesaikan soal cerita pada materi kesebangunan kelas IXA SMP Negeri 3 Cibadak masih rendah. Kesulitan sebagian besar siswa yang mendapatkan nilai rendah adalah (1) siswa kurang mampu dalam memodelkan soal berbentuk cerita materi kesebangunan kedalam bentuk visual, gambar ataupun simbol, (2) siswa belum mampu menghubungkan konsep dari materi kesebangunan dengan materi bangun datar dan (3) siswa banyak yang melakukan prosedur perhitungan yang salah pada prosedur perhitungan perbandingan. Dari hasil tes siswa belum mampu menggunakan semua informasi dari masalah yang ada

\section{DAFTAR PUSTAKA}

Baki, A. (2009). World Conference on Educational Sciences 2009 Conceptions of high school students about mathematical connections to the reallife, (December 2015).

https://doi.org/10.1016/j.sbspro.2009.0 1.247

Businskas, A. M. (2008). Conversations about Connections: How secondary mathematics teachers conceptualize and contend with mathematical connections by thesis submitted in partial fulfillment of the requirements for the degree of In the Faculty of Education.

Kaur, B., \& Lam, T. T. (2010). Reasoning , Communication and Connections in Mathematics : An Introduction, 1-10.

Lestari, D. (2017). Analisis Koneksi Matematis Siswa Kelas VII Dalam Menyelesaikan Soal Cerita Pada Himpunan. dalam soal cerita dalam langkah kerja penyelesaian masalah, sehingga berakibat kepada kesalahan dalam menghubungkan dengan koneksi konsep dan prosedur maka diperoleh jawaban yang tidak relevan.

Hasil penelitian ini dapat memberikan informasi kepada guru bahwa kemampuan koneksi matematis terutama dalam koneksi pemodelan, koneksi konsep dan koneksi prosedur sangat penting untuk diperhatikan dan harus dibangun dalam proses pembelajaran yang dapat memfasilitasi pengembangan kemampuan koneksi matematis siswa.

Muhammad, K., \& Fauzi, A. (2011). P - 11 Peningkatan Kemampuan Koneksi Matematis dan Kemandirian Di Sekolah Menengah Pertama, 978-979.

NCTM. (2000). Principles and Standards for School Mathematics.

Pratiwi Dwi Warih, I Nengah Parta, S. R. (2016). Analisis kemampuan koneksi matematis siswa kelas viiipada materi teorema pythagoras, (Knpmp I), 377384.

Prayitno, A. T. (2018). Proses Berpikir Mahasiswa dalam Membuat Koneksi Matematis Pada Soal Pemecahan Masalah, 4(1), 67-77.

Sajadi, et al (2013). The Examining Mathematical Word Problems Solving Ability under Efficient Representation Aspect, 2013, 1-11. https://doi.org/10.5899/2013/metr00007 